\title{
Quick fixes not on the cards
}

\section{Washington}

GENE therapy in humans, in recent months a popular topic for moral pronouncements from theologians, philosophers and activists, continues to face substantial technical obstacles as well. And even when the techniques become available, only a few of the 3,000 known genetic disorders are likely to be treatable and some of the most familiar and most debilitating disorders such as thalassaemia and sicklecell anaemia are unlikely to be among the early successes.

"Exaggerated expectations as well as exaggerated fears are very common", said Dr James Wyngaarden, director of the National Institutes of Health (NIH), which last week sponsored a public forum on human gene therapy. Only 300 genetic diseases have been defined biochemically, and fewer than a score of human genes of potential importance in treating genetic defects have been cloned. But more important, according to Dr French Anderson, director of the Laboratory of Molecular Hematology at NIH, there are still no methods for delivering genes to human cells, ensuring their expression and ensuring the safety of such procedures.

Anderson and other researchers who spoke at the forum predicted that the first applications in humans will be attempts to correct "classic" inborn errors of metabolism - such as phenylketonuria and Lesch-Nyhan syndrome - that involve a single missing enzyme, leading to the accumulation of a toxic substance in the body. These disorders would be particularly amenable to gene therapy because neither the regulation nor the location in the body of the introduced gene would matter; so long as the missing gene can be inserted and made to function sufficiently well, it makes no difference where in the body it is functioning. The problem of targeting to a specific organ is also avoided if the disorder can be corrected in a relatively accessible organ, such as bone marrow, which can be removed, treated and then replaced.

Diseases such as diabetes, thalassaemia and coagulation disorders, which require precise regulation of the amount of enzyme product produced, will be far less tractable. The limitations that classic transformation techniques place on the number of transformed cells that can reasonably be introduced further narrows the field. According to Dr Joseph Schulman of George Washington University Medical Center, this means that the first successes will most probably come in treating disorders where the body exerts a natural selective pressure in favour of the transformed cells. Adenosine deaminase (ADA) deficiency and Lesch-Nyhan syndrome are promising candidates. Both are also of intense concern because of their debili-

tating effects and the dismal lack of conventional treatments. ADA deficiency causes a serious immune disorder; LeschNyhan, which is a deficiency in the enzyme hypoxanthine-guanine phosphoribosyl transferase, results in an accumulation of uric acid with a disastrous toll on the kidneys and bizarre self-destructive behaviour that often requires the patient to be physically restrained.

Experience so far with animal models of gene therapy, notably the preimplantation alteration of mouse embryos by microinjection of genes, may have only a limited application in humans. Apart from the high rate of failure in the mouse experiments and the ethical considerations of germ-line alterations that such techniques would raise in human use, Schulman noted that ultimately the questions of safety and effectiveness can only be answered by research in humans.

On the question of germ-line alteration - the target earlier this year of an apocalyptypically-worded petition instigated by anti-genetic-engineering activist Jeremy Rifkin and signed by a broad spectrum of US clergymen - both researchers and

\section{Medical ethics}

\section{INSERM sets up forum}

PRESIDENT François Mitterrand may open a hornets' nest on Friday, when he presides at the first session of the new ethics committee of the French medical research council INSERM. Mercifully, the session will be short and probably formal, but when the committee is in full flight next year the stings may come thick and fast.

The ethics committee has been given a very broad brief, enabling it to study "moral problems raised by research in biology, medicine and health" where these concern "the individual, social groups or the whole society". The committee may also concern itself with anything that troubles the public mind in relation to biological research, a formula that leaves open the question of the use of animals.

In true democratic spirit, Mitterrand has ensured that all possible conflicting groups are represented on the committee, which is divided into three sections: in the first section, five representatives of the " "principal philosophical families", Catholicism, Protestantism, Judaism, Mohammedanism and Communism (an interesting twist) nominated by Mitterrand; in the second section, fifteen chosen for their competence and interest in ethical issues, nominated by various bodies such as the National Assembly, the Senate and the Court of Appeal; and in the third, fifteen scientists nominated by research institutions. From the last two sections, a working party of eight will be nominated. The president of the whole committee is to ethicists who spoke last week urged caution and the need for careful thought about the implications. John Fletcher, assistant to the director of $\mathrm{NIH}$ for bioethics and an Episcopal minister, said that although he was satisfied with the "system of ethics and morality in place to handle somatic cell alteration, a similar system had not been developed for germ-line alterations. But", he added, "I am in favour of keeping an open mind."

Several researchers emphasized a dimension of the moral debate that has been less obvious in recent discussions the viewpoint of the victims of genetic disease and the propriety of society eschewing possible solutions to their condition. "For all the talk about scientists' pushing to do gene therapy", Anderson said, "the one thing that isn't discussed is the pressure from the patients themselves." And Ola Huntley, whose personal experience with sickle-cell anaemia in her three children has led her to a professional involvement in counselling sickle-cell patients, expressed her side of the moral conflict simply and directly: "I am angry that anyone presumes to deny my children the essential genetic treatment of a genetic disease. I see such persons as simplistic moralists."

Stephen Budiansky

be Professor Jean Bernard, president of the Academy of Sciences.

Already, this structure has led to argument: why should Mitterand name our experts, a senior Catholic asked recently? What would trade unions say if Mitterrand was free to name their representatives on negotiating committees? Why should communism be represented on equal terms with religion? And why were none of the first section of the committee essentially, the experts in ethics - allowed to be members of the working group, which will no doubt be the heart of the committee? This smacks of technocracy, and hints that the committee will be "soft" on the scientists, says Jesuit Paul Valadier, editor of the magazine Etudes. Certainly, whatever its recommendations, President Mitterrand's presence on Friday will give them political weight.

No-one is in much doubt that the first issues to be touched by the committee will concern in vitro fertilization and the use of fetal tissue; there is more doubt, however, over what conclusions the committee will reach. Some therefore feel that its role will be much more important in stimulating debate and organizing public discussion than in reaching judgements. This, indeed, was one of the goals of INSERM directorgeneral Philippe Lazar in establishing the committee in the first place. But ultimately it will be up to the committee itself to decide exactly how openly it will operate.

Robert Walgate 